\section{Root canal filling using Resilon: a review}

\author{
D. J. Shanahan ${ }^{1}$ and H. F. Duncan ${ }^{2}$
}

VERIFIABLE CPD PAPER
IN BRIEF

- Aims to comprehensively review Resilon as a root filling material in practice.

- Highlights that current research although extensive it is of limited quality.

- Suggests that prospective clinical studies comparing Resilon to existing materials are required.

- Concludes that Resilon cannot yet be considered an evidence-based replacement to gutta-percha.

Root canal treatment is achieved by chemo-mechanical debridement of the root canal system followed by filling. The filling material 'entombs' residual bacteria and acts as a barrier which prevents the entrance of oral microorganisms and reinfection of the root canal system through microleakage. However, filling with contemporary root filling materials such as gutta-percha offers limited long-term resistance to microorganisms; as a result other materials such as Resilon have been investigated as alternatives. The aim of this review was to analyse the literature to consider whether Resilon is a suitable root canal filling material. A MEDLINE and Cochrane library search including various keyword searches identified several papers which investigated or discussed Resilon or RealSeal/Epiphany. Analysis of the literature demonstrated that the bulk of the literature is in vitro in nature, based largely on leakage-type studies, and demonstrates a wide variety of methodologies with conflicting findings; as a result meaningful conclusions are difficult. Within the limit of these in vitro studies Resilon appears to perform adequately in comparison to gutta-percha, however, as a result of the questionable merit of such studies, it cannot presently be considered an evidence-based alternative to the current gold standard gutta-percha. It is imperative that before Resilon is considered as a replacement material, a better understanding of the physical properties of the resin sealer and the reality of the adhesive 'monoblock' are elucidated. The literature also demonstrates a paucity of quality long-term clinical outcome studies which will need to be addressed before firm conclusions can be reached.

\section{INTRODUCTION}

The biological aim of endodontic treatment is to eliminate or prevent apical periodontitis. ${ }^{1}$ This is achieved by chemomechanical debridement of the root canal space followed by obturation. The role of a root canal filling material is to seal the disinfected canal apically, laterally and coronally. If the coronal seal fails the root canal filling should ideally prevent reinfection and the spread of microorganisms and their byproducts towards the tooth apex..$^{2-4}$ In addition a root filling material should be easily introduced into the canal, dimensionally stable, biocompatible, bactericidal (or at least discourage bacterial growth), sterile, radiopaque, readily removed and should not stain tooth structure. ${ }^{5}$ Finally, the root canal filling material should

1.2* Division of Restorative Dentistry and Periodontology, Dublin Dental University Hospital, Trinity College Dublin, University of Dublin, Dublin, Ireland

${ }^{*}$ Correspondence to: Henry F. Duncan

Email: hal.duncan@dental.tcd.ie

\section{Refereed Paper}

Accepted 10 June 2011

DOI: $10.1038 /$ sj.bdj.2011.573

${ }^{\circ}$ British Dental Journal 2011; 211: 81-88 strengthen the remaining root structure. ${ }^{6}$

Gutta-percha has been the obturation material of choice for many years. It has a proven track record, is considered the 'gold standard' and possesses many of the features of an ideal root filling material. However, it does not bond to tooth structure and its ability to prevent leakage has been questioned..$^{7-16}$ In addition, it does not strengthen endodontically treated teeth ${ }^{6}$ and it is not possible to completely remove it during retreatment. ${ }^{17,18}$

In an attempt to address these shortcomings the use of materials which bond to the root canal dentine have been investigated; these include glass ionomers ${ }^{19}$ and resins. ${ }^{20}$ Several resin sealers such as AH-26/ AH-plus (Dentsply Maillefer, Ballaigues, Switzerland), Endorez (Ultradent Products, South Jordan, Utah, USA) Realseal (Pentron Clinical Technologies, Wallingford, Connecticut, USA) and Epiphany (Sybron Dental Specialities, Orange, California, USA) have recently become available. The aim of these resin bonding systems is to allow for the adhesion of the obturation material, sealer and dentine to one another with the aim of creating a 'monoblock'; this forms a hermitic seal increasing resistance to fracture. ${ }^{6}$ A potential drawback of bonding to the tooth surface is the inability to remove the material effectively during retreatment. ${ }^{21}$

Resilon (Resilon Research, LLC, Madison, Connecticut, USA) is a thermoplastic synthetic polymer-based root canal obturation material that was introduced in 2004. ${ }^{22}$ It contains methacrylate resin, bioactive glass, barium sulphate and bismuth oxychloride. ${ }^{22,23}$ It is claimed that the handling characteristics are similar to gutta-percha, and therefore traditional obturation techniques can be used. ${ }^{22}$ The accompanying sealant Epiphany/RealSeal is a dual-curable resin based composite (RBC) sealer. The matrix is a mixture of Bisphenol A epoxy (Bis-GMA), urethane dimethacrylate (UDMA) and hydrophilic dysfunctional methacrylates, while the filler consists of calcium hydroxide, barium sulphate, barium glass and silica. ${ }^{23}$

A series of recent studies have claimed that Resilon has several characteristics which offer an improvement over guttapercha. ${ }^{22,24,25}$ However, attention has tended 
Table 1 Studies which demonstrated Resilon to be statistically superior to gutta-percha in preventing leakage

\begin{tabular}{|c|c|c|c|c|c|}
\hline Reference & Type of study & $\begin{array}{l}\text { Apical or coronal } \\
\text { seal investigated }\end{array}$ & Leakage model & Duration & $\begin{array}{l}\text { Sample size } \\
\text { (number of canals) }\end{array}$ \\
\hline Shipper et al. $2004^{22}$ & In vitro & Coronal & Bacterial & 30 days & 156 \\
\hline Shipper et al. $2005^{26}$ & Animal (dog) & Coronal & Bacterial & 14 weeks & 56 \\
\hline Aptekar and Ginnan $2006^{49}$ & In vitro & Apical & Dye & 3 months & 66 \\
\hline Sagsen et al. $2006^{50}$ & In vitro & Apical & Fluid filtration & Immediate & 36 \\
\hline Stratton et al. $2006^{51}$ & In vitro & Coronal & Fluid filtration & Immediate & 140 \\
\hline Tunga and Bodrumlu $2006^{52}$ & In vitro & Apical & Dye & Immediate & 42 \\
\hline Tunga and Bodrumlu $2006^{53}$ & In vitro & Coronal & Fluid filtration & Immediate & 66 \\
\hline Bodrumlu and Tunga $2007^{54}$ & In vitro & Coronal & Dye & Immediate & 72 \\
\hline Ishimura et al., $2007^{55}$ & In vitro & Coronal & Dye & 30 days & 32 \\
\hline Verissimo et al. $2007^{56}$ & In vitro & Apical & Dye & 7 days & 70 \\
\hline Wedding et al. $2007^{57}$ & In vitro & Coronal & Fluid filtration & 90 days & 46 \\
\hline Kocak et al. $2008^{58}$ & In vitro & Apical & Dye & 3 days & 55 \\
\hline Shin et al. $2008^{59}$ & In vitro & Coronal & Bacterial & 4 weeks & 160 \\
\hline Duggan et al. $2009^{60}$ & Animal (dog) & Coronal & Bacterial & 16 weeks & 66 \\
\hline Moura-Netto et al. $2009^{61}$ & In vitro & Apical & Dye & Immediate & 60 \\
\hline Nawal et al. $2011^{62}$ & In vitro & Coronal & Bacterial & 30 days & 40 \\
\hline
\end{tabular}

to focus on the advantage or otherwise of the resin sealers over conventional sealers rather than the obturation system in comparison to gutta-percha. ${ }^{26}$ The aim of this review was to analyse the literature assessing Resilon in order to investigate firstly whether it is a suitable root canal filling material and also whether it is an evidencebased alternative material to gutta-percha.

\section{REVIEW}

\section{Search strategy}

A MEDLINE and Cochrane library search up to May 2011 was conducted using various keyword combinations including the terms 'Resilon', 'Epiphany', 'RealSeal' and 'Resin sealer'. In addition, bibliographies of all relevant papers and previous review articles were hand-searched. Any relevant work published in the English language and presenting pertinent information related to Resilon was considered for inclusion in the review. The combinations of search terms produced a list of 205 publications from MEDLINE and other sources. Initially, these titles and abstracts were screened. Thereafter, full text analysis was performed of the potentially relevant publications. Publications from the same author discussing identical issues were identified and the more relevant publications were selected for this review. Finally the articles were allocated to several categories for analysis according to the ideal requirements of a root filling material. ${ }^{5}$

\section{Fracture resistance/root strengthening}

Endodontically treated teeth are considered more susceptible to fracture ${ }^{27}$ and a proposed advantage of adhesive obturation systems, such as Resilon, is to reduce this by creating a "monoblock.28 Advocates of the system claim that a mechanically homogenous unit is formed between the root dentine and the obturation material, reinforcing the root. ${ }^{6,22}$ However, the unpredictable nature of intra-radicular dentine bonding has led to uncertainty over the Resilon/Epiphany 'monoblock.29 Successful bonding of Epiphany to dentine has been shown to be difficult to achieve in even simple root canal systems where gap formation was common at the interface between the sealer and root canal wall. ${ }^{29}$ The unpredictable bond between Epiphany and root canal dentine has been attributed to polymerisation shrinkage, ${ }^{30}$ incomplete sealer-polymerisation as a result of residual uncured monomer, ${ }^{31}$ or as a result of the complex mechanical and anatomical challenge of root canal bonding. ${ }^{32-34}$ Therefore, at present the clinical reality of a 'monoblock' is questionable. ${ }^{35-37}$

Early studies compared the fracture resistance of roots obturated with Resilon/ Epiphany compared to gutta-percha and an epoxy resin sealer. ${ }^{6,24}$ It was concluded that the Resilon system increased fracture resistance. This was corroborated by a later study comparing resin-based obturation system to gutta-percha. ${ }^{25}$ Other studies have found the opposite when Resilon was used in immature roots; perhaps this is due contraction stress during polymerisation. ${ }^{38-40}$ Concerns have been raised about the strengthening effect of the Resilon/ Epiphany system as the modulus of elasticity between dentine and Resilon differs; ${ }^{41,42}$ this is likely to lead to breakdown of the adhesive bond. Other studies have demonstrated that Resilon is not mechanically stiff enough to give mechanical support to dentine after root canal treatment. ${ }^{43-46}$

\section{Sealing ability/leakage}

Over the last five years a plethora of leakage studies comparing the sealability of Resilon and gutta-percha have been 


\begin{tabular}{|c|c|c|c|c|c|}
\hline Reference & Type of study & $\begin{array}{l}\text { Apical or coronal } \\
\text { seal investigated }\end{array}$ & Leakage model & Duration & $\begin{array}{l}\text { Sample size } \\
\text { (number of canals) }\end{array}$ \\
\hline Tay et al. $2005^{36}$ & In vitro & Apical & Dye & 3 hours & 20 \\
\hline Biggs et al. $2006^{63}$ & In vitro & Coronal & Fluid filtration & Immediate & 96 \\
\hline Dultra et al. $2006^{64}$ & In vitro & Apical & Dye & 7 days & 40 \\
\hline Pitout et al. $2006^{65}$ & In vitro & Coronal & Bacterial and dye & 72 hours and 3 months & 110 \\
\hline Baumgartner et al. $2007^{66}$ & In vitro & Coronal & Bacterial & 50 days & 36 \\
\hline Bodrumlu \&t Tunga $2007^{67}$ & Invitrp & Apical & Fluid filtration & Immediate & 70 \\
\hline De-Deus et al. $2007^{68}$ & In vitro & Coronal & Bacterial & 9 weeks & 80 \\
\hline Kaya et al. $2007^{69}$ & In vitro & Coronal & Glucose penetration & 30 days & 156 \\
\hline Muñoz et al. $2007^{70}$ & In vitro & Coronal & Bacterial & 30 days & 26 \\
\hline Raina et al. $2007^{71}$ & In vitro & Apical & Fluid filtration & Immediate & 22 \\
\hline Shemesh et al. $2007^{72}$ & In vitro & Coronal & Glucose penetration & 4 weeks & 50 \\
\hline Silveria et al. $2007^{73}$ & In vitro & Apical & Dye & Immediate & 108 \\
\hline Belli et al. $2008^{74}$ & In vitro & Coronal & Fluid filtration & 24 weeks & 44 \\
\hline Fransen et al. $2008^{75}$ & In vitro & Coronal & Bacterial & 65 days & 73 \\
\hline Kocak et al. $2008^{58}$ & In vitro & Apical & Dye & 3 days & 55 \\
\hline Hollanda et al. $2009^{76}$ & In vitro & Coronal & Bacterial & 60 days & 40 \\
\hline Lyons et al. $2009^{77}$ & In vitro & Coronal & Bacterial & 28 days & 80 \\
\hline Kazandağ et al. $2010^{78}$ & In vitro & Coronal & Glucose penetration & 3 weeks & 120 \\
\hline Shokouhinejad et al. $2010^{79}$ & In vitro & Coronal & Bacterial & 60 days & 100 \\
\hline
\end{tabular}

\section{Table 3 Studies which demonstrate gutta-percha to be statistically superior to Resilon in preventing leakage}

\begin{tabular}{|c|c|c|c|c|c|}
\hline Reference & Type of study & $\begin{array}{l}\text { Apical or coronal } \\
\text { seal investigated }\end{array}$ & Leakage model & Duration & $\begin{array}{l}\text { Sample size } \\
\text { (number of canals) }\end{array}$ \\
\hline Onay et al. $2006^{80}$ & In vitro & Apical & Fluid filtration & Immediate & 70 \\
\hline Shemesh et al. $2006^{81}$ & In vitro & Coronal & $\begin{array}{l}\text { Fluid filtration and } \\
\text { glucose penetration }\end{array}$ & 8 weeks and 56 days & 120 \\
\hline Paqué \&t Sirtes $2007^{82}$ & In vitro & Apical & Fluid filtration & Immediate/16 months & 90 \\
\hline De-Deus et al. $2008^{83}$ & In vitro & Coronal & Fluid filtration & 14 months & 40 \\
\hline Jack \&t Goodell $2008^{84}$ & In vitro & Coronal & Fluid filtration & Immediate & 34 \\
\hline Pasqualini et al. $2008^{85}$ & In vitro & Apical & Bacterial & 47 days & 88 \\
\hline Saleh et al. $2008^{86}$ & In vitro & Coronal & Bacterial & 135 days & 110 \\
\hline De Bruyne \&t De Moor $2009^{87}$ & In vitro & Apical & Capillary flow porometry & 6 months & 60 \\
\hline Korkorikos et al. $2009^{88}$ & In vitro & Apical & Fluid filtration & 12 months & 98 \\
\hline Hirai et al. $2010^{89}$ & In vitro & Apical & Fluid filtration & Immediate & 64 \\
\hline Santos et al. $2010^{90}$ & In vitro & Coronal & Fluid filtration & Immediate/180 days & 82 \\
\hline
\end{tabular}

published; these studies form the bulk of the scientific research on Resilon. All of this literature is in vitro in nature comparing gutta-percha to Resilon/Epiphany and other sealers. Although the clinical relevance of these studies has been questioned ${ }^{47,48}$, their conclusions are worthy of discussion due to a paucity of clinical data on Resilon. Several studies suggest that Resilon reduces leakage compared to gutta-percha (Table 1);22,26,49-62 others suggest no difference (Table 2), ${ }^{36,63-}$ ${ }^{79}$ while some report increased leakage with Resilon compared to gutta-percha (Table 3). ${ }^{80-90}$ However, analysis of leakage studies must be carried out with caution as a 'superior' result has a different meaning depending on the technique employed. For example, in a dye penetration test a 
reduced line of colour adjacent to the root filling material suggests a 'superior' result, while in a bacterial leakage test a 'superior' result occurs when bacteria reach the lower collection chamber later.

It is not clear what accounts for this variability, however, it may be due to a lack of standardisation and reliability of leakage studies, which hinders comparison. ${ }^{91}$ Other possible causes of experimental variation include unpredictable setting of resin materials in moist canals, ${ }^{92}$ chelating agents affecting the bond quality,,$^{93}$ certain irrigants affecting polymerisation ${ }^{94-96}$ or the type of curing light affecting polymerisation shrinkage and subsequent leakage. ${ }^{97}$ All these in vitro leakage studies are evaluated over a number of days or weeks and it has been suggested that this may give a false perspective of the behaviour of resin sealers as they may degrade ${ }^{88}$ or hydrolysis with time..$^{35,98}$ Therefore, before any meaningful conclusions can be made long-term evaluations and clinical studies are necessary.

In one animal leakage study Resilon/ Epiphany was compared to gutta-percha/ AH-26 sealer and the resolution of induced apical periodontitis monitored. ${ }^{26}$ The study was carried out over six months on seven Beagle dogs. It was concluded that there was a comparative reduction in apical periodontitis compared to gutta-percha; it must be stressed however that the authors had a financial interest in the Resilon system.

\section{Biocompatibility}

Several in vitro studies have investigated the biocompatability of Resilon without sealer and reported it to compare favourably to gutta-percha ${ }^{99-101}$ This has been corroborated in an animal study. ${ }^{102}$ Other studies have compared Resilon to guttapercha and concluded that Resilon was more biocompatible, ${ }^{103}$ however, another demonstrated the opposite. ${ }^{104}$ It was suggested that a reason for Resilon's potential cytotoxicity may be due to the biodegradability of Resilon by enzymes and alkaline hydrolysis, which would expose the more toxic polymer matrix. ${ }^{36,98}$

Epiphany sealer has been shown to be cytotoxic when compared to zinc oxide eugenol and epoxy-resin based sealers ${ }^{100,105-110}$ with one study suggesting that it became more cytotoxic with increased exposure time. ${ }^{111}$ However, it has also been demonstrated that although Epiphany was cytotoxic it did not effect the viability of human leucocytes. ${ }^{112}$ The reported cytotoxicity may be due to the leakage of uncured monomer from the oxygen inhibition layer, ${ }^{100,101,113,114}$ or due to the degradation of the sealer in an aqueous environment. ${ }^{115-117}$ The Bis-GMA and UDMA contained within the Epiphany bonding agent are another potential source of cytotoxicity. ${ }^{99,101,105,118}$ However, several in vivo studies have shown the biocompatibility of Epiphany to be acceptable. ${ }^{119-124}$

\section{Physical properties}

\section{Setting times}

Resilon's manufacturers claim that an immediate coronal seal can be produced by light curing for 40 seconds, while the remaining sealer sets in 25 minutes (RealSeal/Epiphany instructions, SybronEndo 2010). However, the reality of this has been questioned. It has been found that in anaerobic conditions, it will set in 30 minutes, but in aerobic conditions it can take up to three weeks, suggesting that Resilon will not completely set in the periradicular tissues should it be extruded. ${ }^{113}$

\section{Radiopaque}

Resilon/Epiphany has demonstrated acceptable radiopacity, exceeding the minimal radiopacity equivalent of $3 \mathrm{~mm}$ of aluminum, as recommended by the American National Standards Institute (ANSI) and the American Dental Association (ADA) ${ }^{125-}$ ${ }^{127}$ (Figs 1a and 1d).

\section{Staining}

Resilon has the potential to cause tooth staining as it is susceptible to enzymatic and alkaline hydrolysis. ${ }^{36,98}$ This biodegradation may result in the leaching of dyes from the material. The formation of a precipitate and associated colour change has also been noted when Resilon is disinfected with $2 \%$ chlorohexidine. ${ }^{128}$ However, a one-year clinical study reported no staining associated with Resilon. ${ }^{129}$

\section{Bacteriocidal/sterile}

Resilon and Epiphany, when investigated individually and in combination, have demonstrated no significant antibacterial or antifungal effect. ${ }^{130-134}$ One study concluded that Epiphany may

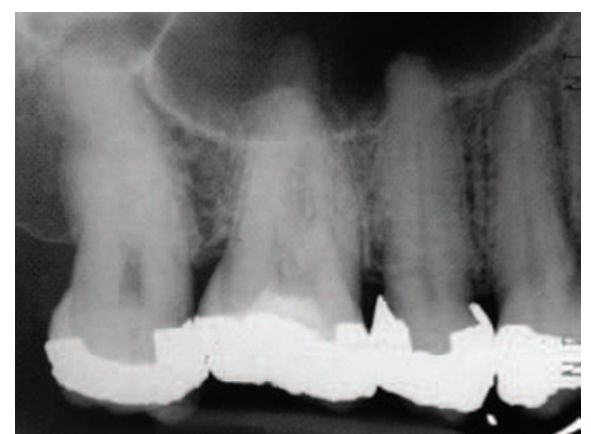

Fig. 1a Preoperative radiograph of 16

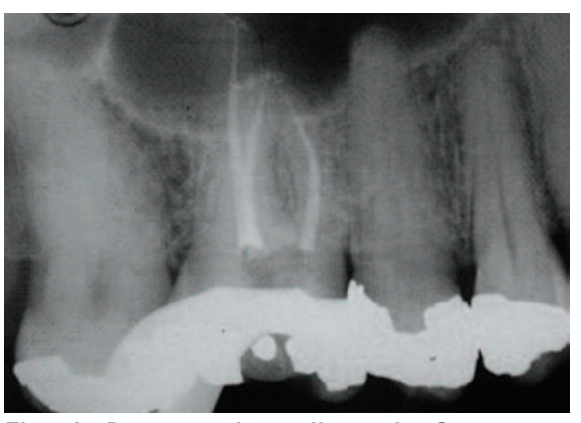

Fig. 1b Postoperative radiograph of a 16 obturated with vertically condensed gutta-percha and an epoxy-resin sealer

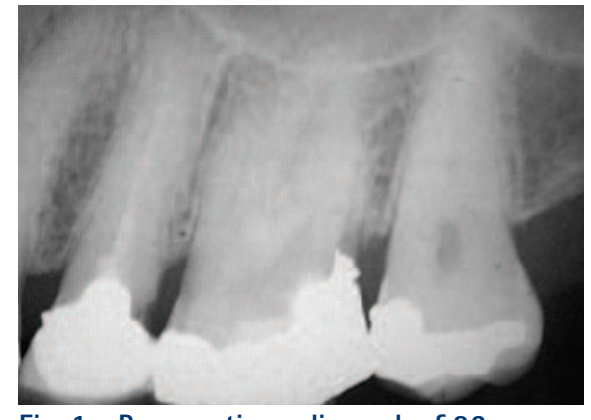

Fig. 1c Preoperative radiograph of 26

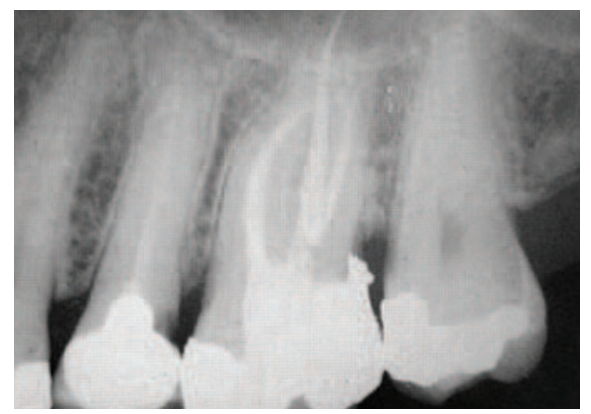

Fig. 1d Postoperative radiograph of a 26 obturated with vertically condensed Resilon and Real Seal sealer. Note the similar radiopacity of the two materials (Figs $1 \mathrm{~b}$ and $1 \mathrm{~d}$ )

actually enhance bacterial growth ${ }^{135}$ and another that Enterococcus faecalis was resistant to Epiphany. ${ }^{133}$ Interestingly, in the latter study it was demonstrated that the Epiphany primer inhibited microbial growth using an agar diffusion method; however, this is unlikely to be clinically relevant. ${ }^{133}$ 


\begin{tabular}{|c|c|c|c|c|c|}
\hline Reference & $\begin{array}{l}\text { Gutta-percha } \\
\text { control sealer }\end{array}$ & Time taken for removal & Residual material & Solvent/Heat used & Removal technique employed \\
\hline Ezzie et al. $2006^{137}$ & AH Plus & Resilon quicker & Less with Resilon & Chloroform or Heat & $\begin{array}{l}\text { ProFile rotary Nickel Titanium } \\
\text { files (NiTi) }\end{array}$ \\
\hline de Oliveira et al. $2006^{138}$ & AH 26 & Resilon quicker & Less with Resilon & Chloroform & K3/Liberator rotary NiTi \\
\hline Schirrmeister et al. $2006^{139}$ & AH sealer & No significant difference & Less with Resilon & None & RaCe rotary NiTi/Hedström files \\
\hline Cunha et al. $2007^{140}$ & AH Plus & No significant difference & Less with Resilon & Chloroform & $K$ files \\
\hline Hassanloo et al. $2007^{141}$ & AH sealer & Resilon removal slower & More with Resilon & + - Chloroform & $\mathrm{K} 3$ rotary NiTi \\
\hline Bodrumlu et al. $2008^{142}$ & AH Plus & Resilon quicker & Less with Resilon & + - Chloroform & Gates Glidden \\
\hline Hammad et al. $2008^{143}$ & various sealers & Not investigated & Less with Resilon & None & ProTaper rotary NiTi/K files \\
\hline lizuka et al. $2008^{144}$ & $\begin{array}{l}\text { Superbond and } \\
\text { Canals N }\end{array}$ & Resilon removal slower & Not measured & $\begin{array}{l}+/ \text { - Heat } \\
+/ \text {-d-limoene-based solvent }\end{array}$ & K3 rotary NiTi \\
\hline Somma et al. $2008^{145}$ & $\begin{array}{l}\text { Kerr Pulp Canal } \\
\text { Sealer + EndoRez }\end{array}$ & Resilon removal slower & More with Resilon & $\begin{array}{l}\text { Chloroform only used } \\
\text { with Gates Glidden + } \\
\text { Hedström group }\end{array}$ & $\begin{array}{l}\text { Mtwo rotary NiTi /ProTaper } \\
\text { NiTi Taper/Gates Glidden + } \\
\text { Hedström files }\end{array}$ \\
\hline Taşdemir et al. $2008^{146}$ & $\begin{array}{l}\text { Gutta Flow System/ } \\
\text { EndoTwinn System } \\
+ \text { AH Plus }\end{array}$ & Resilon removal slower & No significance difference & Chloroform & Mtwo Rotary NiTi \\
\hline Ring et al. $2009^{147}$ & AH sealer & $\begin{array}{l}\text { "Realseal" removed } \\
\text { faster }\end{array}$ & $\begin{array}{l}\text { More debris remaining } \\
\text { with 'Realseal' }\end{array}$ & Chloroform/Orange Solvent & $\begin{array}{l}\text { EndoSequence rotary NiTi/ } \\
\text { ProTaper rotary NiTi }\end{array}$ \\
\hline Zarei et al. $2009^{148}$ & AH 26 sealer & No significant difference & $\begin{array}{l}\text { More debris remaining } \\
\text { with Resilon }(p=0.009)\end{array}$ & Chloroform & RaCe rotary NiTi \\
\hline Fenoul et al. $2010^{149}$ & $\begin{array}{l}\text { MMSeal (an epoxy } \\
\text { based rein sealer) }\end{array}$ & No significant difference & No significant difference & $\begin{array}{l}\text { Tetrachloro-ethylene } \\
\text { based solvent }\end{array}$ & $\begin{array}{l}\text { R-Endo rotary NiTi and } \\
\text { Hedström files }\end{array}$ \\
\hline Marfisi et al. $2010^{150}$ & AH plus sealer & No significant difference & Less with Resilon & None & $\begin{array}{l}\text { ProTaper rotary NiTi } \\
\text { Mtwo Rotary NiTi } \\
\text { Twisted File }\end{array}$ \\
\hline
\end{tabular}

\section{Removal of Resilon}

An ideal requirement of a root canal filling material is that it should be readily retrievable to facilitate post-space preparation or retreatment. Although gutta-percha is considered relatively easy to remove it has been found that regardless of technique employed, complete removal of gutta-percha is not possible during retreatment. ${ }^{18,17,136}$ An advantage of Resilon is that it can be removed in a similar manner to gutta-percha (Table 4). ${ }^{137-150} \mathrm{~A}$ series of studies have compared the removal of Resilon to guttapercha with the time taken for removal and residual material remaining the main variables investigated. Most studies have concluded that Resilon is readily removable using a variety of techniques. As with the sealability studies the results have been contradictory with some studies demonstrating the amount of residual debris to be less than that of gutta-percha root fillings, ${ }^{137-140,142}$ while others have found the opposite. ${ }^{141,145,148}$ The variation between these studies maybe attributable to Resilon/ Epiphany not completely setting before retreatment and therefore being easier to remove, ${ }^{113,133}$ or that the canals were retreated to two sizes larger than the apical size before filling which would enhance the efficacy of retreatment. ${ }^{151-153}$ Ezzie and co-workers ${ }^{137}$ found that Resilon left less residual debris in the apical third of the root canal; this may be due to the fact that effective removal of the smear layer and subsequent bonding is difficult to achieve in this area. ${ }^{154,155}$ The vast majority of studies have compared Resilon/Epihany to guttapercha and epoxy resin cement, however, this may prevent accurate extrapolation to other gutta-percha sealers as epoxy resins are associated with a higher level of residual debris than other cements. ${ }^{156}$

Chloroform has been recommended by the manufacturers as an aid in removal of Resilon (RealSeal/Epiphany instructions, SybronEndo 2010). However, resin sealers are not dissolved by chloroform and it has an adverse effect on bond strength of Resilon/Epiphany when reobturating. ${ }^{157,158}$

\section{Clinical outcome studies}

Randomised prospective clinical outcome studies comparing two different treatments are the gold standard in medical research. These studies are uncommon in endodontics and those published are often of low quality. ${ }^{159}$ To date only one clinical study has compared Resilon/Epiphany to gutta-percha/Kerr's sealer and it concluded that the outcome for both materials was not statistically different. ${ }^{160}$ However, this was a retrospective study with follow-up ranging from one month to two years; in addition there was only a limited number in each group. Other case-series studies have reported only on the outcome of Resilon/Epiphany obturated teeth without comparing to gutta-percha. ${ }^{129,161}$ In one retrospective study post-treatment radiographs were examined after one year and it was concluded that Resilon healing rates were similar to that of gutta-percha obturated canals. ${ }^{161}$ However, the review period was short, the numbers of teeth relatively small and there was no clinical examination. The short-term clinical effectiveness of Resilon/Epiphany was corroborated in a prospective study with both clinical and radiographic assessment being used to evaluate outcome. ${ }^{129}$ This study was 
preliminary in nature with only a small number of teeth treated and reviewed after one year.

\section{CONCLUSIONS}

Root canal filling is a key step in nonsurgical endodontic treatment. The majority of recent studies have focused on the relative ability of Resilon to resist leakage; however, the results have been largely inconclusive with a group of studies suggesting Resilon is superior to gutta-percha and another group the opposite. The heterogeneity of methods employed within these studies makes comparison difficult and the clinical relevance of these in vitro studies is dubious. What can be concluded, however, is that although there is evidence to suggest that Resilon performs better and indeed worse than gutta-percha in leakage studies, it is difficult to extrapolate meaningful clinical conclusions from this literature. Perhaps a more relevant way of assessing the efficacy of Resilon would be to assess outcome in vivo; unfortunately these studies are time consuming and rare within endodontics. The literature suggests that Resilon is not stiff enough to strengthen residual root structure; however, more information is required on the nature of the adhesive bond between sealer and root dentine and whether the reported in vitro 'monoblock' is translated clinically. The predictability of bonding in the apical reaches of the root canal remains to be elucidated as the use of resin sealers and bonding within the root canal is relatively new. The techniques and materials are likely to evolve over the next few years; this may lead to an improvement in both our knowledge and results. In terms of biocompatibility and physical properties Resilon appears to perform well comparing favourably to gutta-percha, although there are concerns regarding the cytotoxicity of the Epiphany sealer. Definitive conclusions cannot be reached as yet with regard to ease of removal compared to gutta-percha, however, it appears to compare favourably to gutta-percha using a variety of removal techniques. There is an absence of randomised clinical outcome studies comparing gutta-percha to Resilon and until these are available it is impossible to adequately assess Resilon as a replacement for gutta-percha which has an established research track record over many years. These outcome studies, perhaps through large multicentred trials, should form the focus of attention rather than further in vitro leakage studies. The issue of whether Resilon is a suitable material is impossible to adequately assess at present and only time will tell if it proves an evidence-based alternative or replacement for gutta-percha.

1. Nair PN R. On the cause of persistent apical periodontitis: a review. Int Endod J 2006; 34: 249-281.

2. Hirsch J M, Ahlstrom U, Henrikson P A, Peterson L E. Periapical surgery. Int J Oral Surg 1979; 8: 173-185.

3. Sundqvist G, Figdor D, Persson S, Sjörgren U. Microbiological analysis of teeth with failed endodontic treatment and the outcome of conservative re-treatment. Oral Surg Oral Med Oral Pathol Oral Radiol Endod 1998; 85: 86-93.

4. Siqueira J F, Rocas I N, Lopes H P, de Uzeda M. Coronal leakage of two root canal sealers containing calcium hydroxide after exposure to human saliva. J Endod 1999; 25: 14-16.

5. Grossman L. Endodontic practice, $11^{\text {th }}$ ed. p 242. Phildelphia, USA: Lea \& Fibiger, 1988.

6. Teixeira F B, Teixeira E C N, Thompson J Y, Trope M. Fracture resistance of roots endodontically treated with a new resin filling material. J Am Dent Assoc 2004; 135: 646-652.

7. Swanson K, Madison S. An evaluation of coronal microleakage in endodontically treated teeth. Part 1. Time periods. J Endod 1987; 13: 56-59.

8. Madison S, Wilcox L. An evaluation of coronal microleakge in endodontically treated teeth. Part III. In vivo study. J Endod 1988; 14: 455-458.

9. Torabinejad M, Ung B, Kettering J. In vitro bacterial penetration of coronally unsealed endodontically treated teeth. J Endod 1990; 16: 566-569.

10. Limkangwalmongkol $S$, Burtscher $P$, Abbot $P$, Sandler A, Bishop B. A comparative study of the apical leakage of four root canals sealers and laterally condensed gutta percha. J Endod 1991: 17: 495-499.

11. Magura M E, Kafrawy A H, Brown C E, Newton C W. Human saliva coronal microleakeage in obturated root canals: An in vitro study. J Endod 1991; 17: 324-331.

12. Khayat $A$, Lee $S \mathrm{~J}$, Torabinejad $M$. Human saliva penetration of coronally unsealed obturated root canals. J Endod 1993; 19: 458-461.

13. Friedman $S$, Torneck C, Komorowsji R, Ouzounian Z, Syrtash P, Kaufman A. In vivo model for assessing the functional efficacy of endodontic materials and techniques. J Endod 1997; 23: 557-561.

14. Oliver $C_{1}$ Abbott P. An in vitro study of apical and coronal micro leakage of laterally condensed gutta-percha with Ketac-Endo and AH-26. Aust Dent J 1998; 43: 262-268.

15. Siqueira J F, Roças I N, Favieri A, Abad E C, Castro A J, Gahyva S M. Bacterial leakage in coronally unsealed root canals obturated with 3 different techniques. Oral Surg Oral Med Oral Pathol Oral Radiol Endod 2000; 90: 647-650.

16. Shipper G, Trope M. In vitro microbial leakage of endodontically treated teeth using new and standard obturation techniques. J Endod 2004: 30: 154-158.

17. Ferreira J J, Rhodes J S, Pitt Ford T R. The efficacy of gutta-percha removal using ProFiles. Int Endod $J$ 2001; 34: 267-274

18. Imura N, Kato A S, Hata G I, Uemura M, Toda T, Weine F. A comparison of the relative efficacies of four hand and rotary instrumentation techniques during endodontic retreatment. Int Endod J 2000; 33: 361-366.

19. Friedman S, Löst C, Zarrabian M, Trope M Evaluation of success and failure after endodontic therapy using a glass ionomer cement sealer. J Endod 1995; 21: 384-390.

20. Zmener 0. Tissue response to a new methacrylate-based root canal sealer: preliminary observations in the subcutaneous connective tissues of rats. J Endod 2004; 30: 348-351.

21. Lee K W, Williams M C, Camps J J, Pashley D H. Adhesion of endodontic sealers to dentin and gutta-percha. J Endod 2002; 28: 684-688.

22. Shipper G, Ørstavik D, Teixeira F B, Trope M. An evaluation of microbial leakage in roots filled with a thermoplastic synthetic polymer-based root canal filling material (Resilon). J Endod 2004; 30: 342-347.

23. Gatwood R S. Endodontic materials. Dent Clin North Am 2007; 15: 695-712.

24. Teixeira F B, Teixeira E C N, Thompson J Y, Leinfelder $K F$, Trope M. Dentinal bonding reaches the root canal system. J Esthet Restor Dent 2004; 16: 348-354.

25. Hammad M, Qualtrough A, Silikas N. Effect of a new obturating material on vertical root fracture resistance of endodontically treated teeth. J Endod 2007: 33: 732-736.

26. Shipper G, Teixeira F B, Arnold R R, Trope M. Periapical inflammation after coronal microbial inoculation of dog roots filled with gutta-percha or resilon. J Endod 2005; 31: 91-96.

27. Reeh E S, Douglas W H, Messer H H. Stiffness of endodontically treated teeth related to restoration technique. J Dent Res 1989; 68: 1540-1544.

28. Tay F R, Pashley D H. Monoblocks in root canals: a hypothetical or a tangible goal. J Endod 2007; 33: 391-398.

29. De-Deus G, Reis C, Di Giorgi K, Brandão M C, Audi C, Fidel R A. Interfacial adaptation of the Epiphany self-adhesive sealer to root dentin. Oral Surg Oral Med Oral Pathol Oral Radiol Endod 2011; 111: 381-386.

30. Tay F R, Loushine R J, Lambrechts P, Weller R N, Pashley D H. Geometric factors affecting dentin bonding in root canals: a theoretical modelling approach. J Endod; 31: 584-589.

31. Nunes V H, Silva R G, Alfredo E, Sousa-Neto M D Silva-Sousa Y T. Adhesion of Epiphany and AH Plus sealers to human root dentin treated with different solutions. Braz Dent J 2008; 19: 46-50.

32. Perdigão J, Lopes M M, Gomes G. Interfacial adaptation of adhesive materials to root canal dentin. J Endod 2007; 33: 259-263.

33. Onay E O, Ungor M, Ari H, Belli S, Ogus E. Push-out bond strength and SEM evaluation of new polymeric root canal fillings. Oral Surg Oral Med Oral Pathol Oral Radiol Endod 2009; 107: 879-885.

34. Costa J A, Rached-Júnior F A, Souza-Gabriel A E Silva-Sousa Y T C, Sousa-Neto M D. Push-out strength of methacrylate resin-based sealers to root canal walls. Int Endod J 2010; 43: 698-706.

35. Gesi A, Raffaelli O, Goracci C, Pashley D H, Tay F R, Ferrari M. Interfacial strength of Resilon and gutta-percha to intraradicular dentin. J Endod 2005; 31: 809-813.

36. Tay FR, Loushine R J, Weller R N et al. Ultrastructural evaluation of the apical seal in roots filled with a polycaprolactone-based root canal filling material. J Endod 2005; 31: 514-519.

37. Tay F R, Hiraishi N, Pashley D H et al. Bondability of Resilon to a methacrylate-based root canal sealer. J Endod 2006; 32: 133-137.

38. Stuart C H, Schwartz S A, Beeson T J. Reinforcement of immature roots with a new resin filling material in a model of apexification. J Endod 2006; 32: 350-353.

39. Wilkinson K L, Beeson T J, Kirkpatrick T C. Fracture resistance of simulated immature teeth filled with Resilon, gutta-percha or composite. J Endod 2007; 33: 480-483.

40. Haemalatha H, Sandeep M, Kulkarni S, Yakub S S. Evaluation of fracture resistance in simulated immature teeth usuing Resilon and ribbond as root reinforcements - an in vitro study. Dent Traumatol 2009; 25: 433-438.

41. Hiraishi N, Papacchini F, Loushine R J et al. Shear bond strength of Resilon to a methacrylate-based root canal sealer. Int Endod J 2005; 38: 753-763.

42. Kazandag M K, Sunay H, Tanalp J, Bayirli G. Fracture resistance of roots using different canal filling systems. Int Endod J 2009; 42: 705-710.

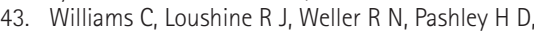


Tay F R. A comparison of cohesive strength and stiffness of Resilon and gutta-percha. J Endod 2006: 32: 553-555

44. Sagsen B, Kahraman Y, Akdogan G. Resistance to fracture of roots filled with three different techniques. Int Endod J 2007: 40: 31-35.

45. Ribeiro F C, Souza-Gabriel A E, Marchesan $M$ A, Alfredo E, Silva-Sousa Y T. Influence of different endodontic filling materials on root fracture susceptibility. J Dent 2008; 36: 69-73.

46. Hanada T, Quevedo C G A, Okitsu M et al. Effects of new adhesive resin root canal filling materials on vertical root fractures. Aust Endod J 2010; 36: 19-23.

47. Ricucci D, Grondahl K, Bergenholtz G. Periapical status of root-filled teeth exposed to the oral environment by loss of restoration or caries. Oral Surg Oral Med Oral Pathol Oral Radiol Endod 2000. 90: 354-349.

48. Kim Y K, Grandini S, Ames J M et al. Critical review on methacrylate resin-based root canal sealers. J Endod 2010; 36: 383-399.

49. Aptekar A, Ginnan K. Comparative analysis of microleakage and seal for two obturation materials: Resilon/Epiphany and gutta-percha. J Can Dent Assoc 2006; 72: 245

50. Sagsen B, Er O, Kahraman Y, Orucoglu H. Evaluation of micro leakage of roots filled with different techniques with a computerized fluid filtration technique. J Endod 2006; 32: 1168-1170.

51. Stratton R K, Apicella M J, Mines P. A fluid filtration comparsion of gutta-percha verus Resilon, a new soft resin endodontic obturation system. J Endod 2006; 32: 642-645.

52. Tunga $U$, Bodrumlu. Apical leakage of Resilon obturation material. J Contemp Dent Pract 2006; 7: $45-52$.

53. Tunga U, Bodrumlu E. Assessment of the sealing ability of a new root canal obturation material. J Endod 2006; 32: 876-878.

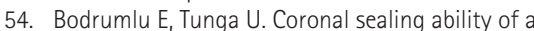
new root canal filling material. J Can Dent Assoc 2007; 73: 623.

55. Ishimura H, Yoshioka T, Suda H. Sealing ability of new adhesive root canal filling materials measured by new dye penetration method. Dent Mater J 2007; 26: $290-295$

56. Verissimo D M, do Vale M S, Monteiro A J. Comparison of apical leakage between canals filled with gutta-percha/AH-plus and Resilon/Epiphany System, when submitted to two filling techniques. J Endod 2007; 33: 291-294.

57. Wedding J R, Brown C E, Legan J J, Moore B K, Vail M M. An in vitro comparison of micro leakage between Resilon and gutta-percha with a fluid filtration model. J Endod 2007; 33: 1447-1449.

58. Kocak M M, Er O, Saglam B C, Yaman S. Apical leakage of Epiphany root canal sealer combined with different master cones. Eur J Dent 2008. 2: 91-95.

59. Shin S, Jee S, Song J, Junbg I, Cha J, Kim E. Comparison of regrowth of Enterococcus faecalis in dentinal tubules after sealing with gutta-percha or Resilon. J Endod 2008; 34: 445-448.

60. Duggan D, Arnold R R, Teixeira F B, Caplan D J Tawil P. Periapical inflammation and bacterial penetration after coronal inoculation of dog roots filled with RealSeal 1 and Thermafil. J Endod 2009; 35: 852-857.

61. Moura-Netto C, Pinto T, Davidowicz H, de Moura A A M. Apical leakage of three resin-based endodontic sealers after 810-nm-diode laser irradiation. Photomed Laser Surg 2009; 27: 891-894.

62. Nawal R R, Parande M, Sehgal R, Rao N R, Naik A. A comparative evaluation of 3 root canal filling systems Oral Surg Oral Med Oral Pathol Oral Radiol Endod. 2011; 111: 387-393.

63. Biggs S C, Knowles K I, Ibarrola J L, Pashley D H. An in vitro assessment of the sealing ability of Resilon Epiphany using a fluid filtration. J Endod 2006; 32: 759-761.

64. Dultra F, Barroso J M, Carrasco L D, Capelli A, Guerisoli D M, Pécora J D. Evaluation of apical microleakage of teeth sealed with four different canal sealers. Appl Oral Sci 2006; 14: 341-345.

65. Pitout E, Oberholzer T G, Blignaut E, Molepo J.
Coronal leakage of teeth root-filled with gutta-percha or Resilon root canal filling material. J Endod 2006: 32: 610-615.

66. Baumgartner $G$, Zehnder M, Paque F. Entercoccus faecalis type strain leakage through root canals filled with gutta-percha/AH plus or Resilon/ Epiphany. J Endod 2007; 33: 45-47.

67. Bodrumlu $E$, Tunga $U$. The apical sealing ability of a new root canal filling material. Am J Dent 2007; 20: 295-298.

68. De-Deus G, Audi C, Murad C, Fidel S, Fidel R A. Sealing ability of oval-shaped canals filled using the System B heat source with either gutta-percha or Resilon: an ex vivo study using a polymicrobial leakage model. Oral Surg Oral Med Oral Pathol Oral Radiol Endod 2007: 104: 114-119.

69. Kaya B U, Kececi A D, Belli S. Evaulation of the sealing ability of gutta-percha and thermoplastic synthetic polymer-based systems along the root canals through glucose penetration model. Oral Surg Oral Med Oral Pathol Oral Radiol Endod 2007; 104: 66-73.

70. Muñoz H R, Saravia-Lemus G A, Florián, Lainfiesta J F. Microbial leakage of Enterococcus faecalis after post space preparation in teeth filled in vivo with RealSeal versus gutta-percha. J Endod 2007; 33: 674-675.

71. Raina R, Loushine R J, Weller R N, Tay F R, Pashley $\mathrm{DH}$. Evaluation of the quality of the apical seal in Resilon/Epiphany and Gutta-percha/AH Plus-filled root canals by using a fluid filtration approach. J Endod 2007; 33: 944-947.

72. Shemesh $H$, van der Bos $M, W u, M K$, Wesselink PR Glucose penetration and fluid transport through coronal root structure and filled root canals. Int Endod J 2007; 40: 866-872.

73. Silveira F F, Soares J A, Nunes E, Mordente V L Negative influence of continuous wave technique on apical sealing of the root canal system with Resilon. J Oral Sci 2007; 49: 121-128.

74. Belli S, Ozcan E, Derinbay O, Eldeniz AU. A comparative evaluation of sealing ability of a new, self etching, dual-curable sealer hybrid root SEAL (MetaSEAL). Oral Surg Oral Med Oral Pathol Oral Radiol Endod 2008; 106: 45-52.

75. Fransen J N, He J, Glickman G N, Rios A, Shulman $J$ D, Honeyman A. Comparative assessment of ActiV GP/glass ionomer sealer, Resilon/Epiphany, and gutta-percha/AH plus obturation: a bacterial leakage study. J Endod 2008; 34: 725-727.

76. Hollanda A C, Estrela C R, Decurcio Dde A, Silva J A Estrela $C$. Sealing ability of three commercial resinbased endodontic sealers. Gen Dent 2009; 57: 368-373.

77. Kazandag M K, Tanalp J, Bayrak Ö F, Sunay H, Bayirh $\mathrm{G}$. Microleakage of various root filling systems by glucose filtration analysis. Oral Surg Oral Med Oral Pathol Oral Radiol Endod 2010; 109: 96-102.

78. Lyons W W, Hartwell G R, Stewart J T, Reavley B, Appelstein C, Lafkowitz S. Comparison of coronal bacterial leakage between immediate versus delayed post-space preparations in root canals filled with Resilon/Epiphany. Int Endod J 2009; 42: 203-207.

79. Shokouhinejad N, Sharifian M R, Aligholi M, Assadian H, Tabor R K, Nekoofar M H. The sealing ability of Resilon and gutta-percha following different smear layer removal methods: an ex vivo study. Oral Surg Oral Med Oral Pathol Oral Radiol Endod 2010; 110: 45-49.

80. Onay $\mathrm{E} \mathrm{O}$, Ungor $\mathrm{M}$, Orucoglu $\mathrm{H}$. An in vitro evaluation of the apical sealing ability of a new resin based root canal obturation system. J Endod 2006; 32: 976-978.

81. Shemesh H, Wu M K, Wesselink P R. Leakage along the apical root fillings with and without smear layer using two different leakage models: a two month longitudinal ex vivo study. Int Endod J 2006; 39: 968-976.

82. Paqué F, Sirtes G. Apical sealing ability of Resilon/ Epiphany versus gutta-percha/AH Plus: immediate and 16 month leakage. Int Endod J 2007; 40: $722-729$

83. De-Deus G, Namen F, Galan J.Reduced long-term sealing ability of adhesive root fillings after water-storage stress. J Endod 2008; 34: 322-325.

84. Jack R M, Goodell G G. In vitro comparison of coronal microleakage between Resilon alone and gutta-percha with a glass ionomer intraorifice barrier using a fluid filtration model. J Endod 2008; 34: 718-720.

85. Pasqualini D, Scotti N, Mollo L et al. Microbial leakage of gutta-percha and Resilon root canal filling material: a comparative study using a new homogenous assay for sequence detection. J Biomater App/ 2007; 22: 337-352.

86. Saleh I M, Ruyter I E, Haapasalo M, Ørstavik D. Bacterial penetration along different root canal filling materials in the presence or absence of smear layer. Int Endod J 2008; 41: 32-40.

87. De Bruyne M A, De Moor R J. Long-term sealing ability of Resilon apical root-end fillings. Int Endod J 2009; 42: 884-892

88. Kokorikos I, Kolokouris I, Economides N, Gogos C, Helvatjoglu-Antoniades M. Long-term evaluation of the sealing ability of two root canal sealers in combination with self-etching bonding agents. J Adhes Dent 2009; 11: 239-246.

89. Hirai V H, da Silva Neto U X, Westphalen V P D Perin C $P$, Carneiro E, Fariniuk L F. Comparative analysis of leakage in root canal filling performed with gutta-percha and Resilon cones with $\mathrm{AH}$ Plus and Epiphany sealers. Oral Surg Oral Med Oral Pathol Oral Radiol Endod 2010; 109: 131-135.

90. Santos J, Tjäderhane L, Ferraz C et al. Long-term sealing ability of resin-based root canal fillings. Int Endod J 2010; 43: 455-460.

91. Wu M K, Wesselink P R. Endodontic leakage studies reconsidered. Part I. Methodology, application and relevance. Int Endod J 1993; 26: 37-43.

92. Zmener O, Pameijer C H, Serrano S A, Vidueira M, Macchi R L. Significance of moist root canal dentin with the use of methacrylate-based endodontic sealers: an in vitro coronal dye leakage study. J Endod 2008; 34: 76-79.

93. De-Deus G, Namen F, Galan J, Zehnder M. Soft chelating irrigation protocol optimizing bonding quality of Resilon/Epiphany root fillings. J Endod 2008; 34: 703-705.

94. Yiu C K, Garcia-Godoy F, Tay F R et al. A nanoleakage perspective on bonding to oxidised dentin. J Dent Res 2002; 81: 628-632.

95. Erdemir A, Ari H, Gungunes H, Belli S. Effects of medications for root canal treatment on bonding to root canal dentin. J Endod 2004; 30: 113-116.

96. Ozturk $\mathrm{B}$, Özer F. Effect of $\mathrm{NaOCl}$ on bond strengths of bonding agents to pulp chamber lateral walls. J Endod 2004; 30: 362-365.

97. Nagas E, Cehreli Z, Durmaz V, Vallittu P, Lassila $L$. Regional push out bond strength and coronal micro leakage of Resilon after different light curing methods. J Endod. 2007; 33: 1464-1468.

98. Tay F R, Pashley D H, Williams M C et al. Susceptability of a polycaprolactone-based root canal filling material to degradation. I. Alkaline hydrolysis. J Endod 2005; 31: 593-598.

99. Key J E, Rahemtulla F G, Eleazer P D. Cytotoxicity of a new root canal filling material on human gingival fibroblasts. J Endod 2006; 32: 756-758.

100. Susini G, About I, Tran-Hung L, Camps J. Cytotoxicity of Epiphany and Resilon with a root model. Int Endod J 2006; 39: 940-944.

101. Merdad K, Pascon A E, Kulkarni G, Santerre P, Friedman $S$. Short-term cytotoxicity assessment of components of the epiphany resin-percha obturating system by indirect and direct contact with Millipore filter assays. J Endod 2007; 33: 24-27.

102. Brasil D S, Soares J A, Horta M C et al. Periapical repair in dog teeth: root canal adhesive filling by using the Resilon System. J Endod 2010; 36: $428-428$.

103. Donadio M, Jiang J, Safavi K E, Zhu Q. Cytotoxicity evaluation of Activ G P, Resilon cones in vitro. Oral Surg Oral Med Oral Pathol Oral Radiol Endod 2008; 106: $76-79$.

104. Economides N, Koulaouzidou E A, Gogos C, Kolokouris I, Beltes P, Antoniades D. Comparative study of the cytotoxic effect of Resilon against two cell lines. Braz Dent J 2008; 19: 291-295.

105. Bouillaguet S, Wataha J C, Tay F R, Brackett M G, 
Lockwood P E. Initial in vitro biological response to contemporary endodontic sealers. J Endod 2006; 32: 989-992.

106. Brackett M G, Marshall A, Lockwood P E et al. Cytotoxicity of endodontic materials over 6-weeks ex vivo. Int Endod J 2008; 41: 1072-1078.

107. Lodiene G, Morisbak E, Bruzell E, Ørstavik D. Toxicity evaluation of root canal sealers in vitro. Int Endod J 2008; 41: 72-77.

108. Al-Hiyasat A S, Tayyar M, Darmani H. Cytotoxicity evaluation of various resin based root canal sealers. Int Endod J 2010; 43: 148-153.

109. Brackett M G, Messer R L, Lockwood P E et al. Cytotoxix response of three cell lines exposed in vitro to dental endodontic sealers. Biomed Mater Res B Appl Biomater 2010; 95: 380-386.

110. Maeda H, Tomokiyo A, Koori K et al. An in vitro evaluation of two resin-based sealers on proliferation and differentiation of human periodontal ligament cells. Int Endod J 2011; 44: 425-431.

111. Heitman E P, Joyce A P, McPherson J C 3rd, Roberts $\mathrm{S}$, Chuang $\mathrm{A}$. An in vitro evaluation of the growth of human periodontal ligament fibroblasts after exposure to a methacrylate-based endodontic sealer. J Endod 2008; 34: 186-189.

112. Baraba A, Želježić D, Kopjar N, Mladinić M, Anić I, Miletić I. Evaluation of cytotoxic and genotoxic effects of two resin-based root-canal sealers and their components on human leucocytes in vitro. Int Endod J 2011; 44: 652-661.

113. Nielsen B A, Beeler W J, Vy C, Baumgartner J C. Setting times of Resilon and other sealers in aerobic and anaerobic environments. J Endod 2006; 32: 130-132.

114. Eldeniz A U, Mustafa K, Ørstavik D, Dahl J E. Cytotoxicity of new resin, calcium hydroxide and silicone-based root canal sealers on fibroblasts derived from human gingival and L929 cell lines. Int Endod J 2007; 40: 329-337.

115. Calvalcanti B N, Rode S M, Marques M M. Cytotoxicity of substances leached or dissolved from pulp capping materials. Int Endod J 2005; 38: 505-509.

116. Versiani M A, Carvalho-Junior J R, Padiha M I, Lacey S Pascon E A, Sousa-Neto M D. A comparative study of physiochemical properties of AH Plus and Epiphany root canal sealants. Int Endod J 2006; 39: 464-471.

117. Donnelly A, Sword J, Nishitani Y et al. Water sorption and solubility of methacrylate resin-based root canal sealers. J Endod 2007; 33: 990-994.

118. Hanks C T, Strawn S E, Wataha J C, Craig R G. Cytotoxic effects of resin components on cultured mammalian fibroblasts. J Dent Res 1991; 70: $1450-1455$

119. Sousa C J, Montes C R, Pascon E A, Loyola A M, Versiani M A. Comparison of the intraosseous biocompatibility of AH Plus, EndoREZ, and Epiphany root canal sealers. J Endod 2006; 32: 656-662.

120. Onay E O, Ungor M, Ozdemir B H. In vivo evaluation of the biocompatibility of a new resin-based obturation system. Oral Surg Oral Med Oral Pathol Oral Radiol Endod 2007; 104: 60-66.

121. de Campos-Pinto $M M$ de Oliveira $D$ A Versiani M A, Silva-Sousa Y T, de Sousa-Neto M D, da Cruz Perez D E. Assessment of the biocompatibility of Epiphany root canal sealer in rat subcutaneous tissues. Oral Surg Oral Med Oral Pathol Oral Radiol Endod 2008; 105: 77-81.

122. Gambarini G, Romeo U, Tucci E et al. Cytotoxicity of Epiphany SE Endodontic sealer: a comparative in vitro study. Med Sci Monit 2009; 15: 15-18.

123. Garcia Lda F, Marques A A, Roselino Lde M, Pires-de-Souza Fde C, Consani S. Biocompatibility evaluation of Epiphany/Resilon root canal filling system in subcutaneous tissue of rats. J Endod 2010; 36: 110-114.

124. Zmener O, Pameijer C H, Kokubu G, Grana D.
Subcutaneous connective tissue reaction to methacrylate resin based and zinc oxide and eugenol sealers. J Endod 2010; 36: 1574-1579.

125. Carvalho-Junior J R, Correr-Sobrinho L, Correr A B, Sinhoreti M A, Sousa-Neto M D. Radiopacity of root filling materials using digital radiography. Int Endod J 2007: 40: 514-520.

126. Bodrumlu E, Gungor K. Radiopacity of an endodontic core material. Am J Dent 2009; 22: 157-159.

127. Resende L M, Rached-Junior F J, Versiani M A et al. A comparative study of physiochemical properties of AH Plus, Epiphany and Epiphany SE root canal sealers. Int Endod J 2009; 42: 785-793.

128. Royal M J, Williamson A E, Drake D R. Comparison of $5.25 \%$ sodium hypochlorite, MTAD, and $2 \%$ chlorhexidine in the rapid disinfection of polycaprolactone-based root canal filling material. J Endod 2007; 33: 42-44.

129. Pawinska M, Kierklo A, Marczuk-Kolada G. New technology in endodontics-the Resilon-Epiphany system for obturation of root canals. Adv Med Sci 2006; 51: 154-157.

130. Bodrumlu E, Semiz M. Antibacterial activity of a new endodontic sealer against Enterococcus faecalis. J Can Dent Assoc 2006; 72 : 637.

131. Melker K B, Vertucci F J, Fernanda R, Progulske-Fox $A$, Bélanger M. Antimicrobial efficacy of medicated root canal filling materials. J Endod 2006; 32: 148-151

132. Bodrumlu E, Alaçam T. The antimicrobial and antifungal activity of a root canal core material. J Am Dent Assoc 2007: 138: 1228-1232.

133. Pinheiro C R, Guinesi A S, Pizzolitto A C, BonettiFilho I. In vitro antimicrobial activity of Acroseal, Polifil and Epiphany against Enterococcus faecalis. Braz Dent J 2009; 20: 107-111.

134. Zhang $H$, Shen, Y, Ruse N D, Haapasalo M. Antibacterial activity of endodontic sealers by modified contact test against Enterococcus faecalis. J Endod 2009; 35: 1051-1055

135. Slutsky-Goldberg I, Slutzky H, Solomonov M, Moshonov J, Weiss E, Matalon S. Antibacteria properties of four endodontic sealers. J Endod 2008; 34: 735-738.

136. Masiero A V, Barletta F B. Effectiveness of different techniques for removing gutta-percha during retreatment. Int Endod J 2005; 38: 2-7.

137. Ezzie E, Fleury A, Solomon E, Spears R, He J. Efficacy of retreatment techniques for a resin based root canal obturation material. J Endod 2006; 32: 341-344.

138. de Oliveira D P, Barbizam J V, Trope M, Teixeira F B. Comparison between gutta-percha and Resilon removal using two different techniques in endodontic retreatment. J Endod 2006; 32: 362-364.

139. Schirrmeister J F Meyer K M, Hermanns $P$ Altenburger M J, Wrbas K T. Effectiveness of hand and rotary instrumentation for removing a new synthetic polymer-based root canal obturation material (Epiphany) during retreatment. Int Endod 2006; 39: 150-156.

140. Cunha R S, De Martin A S, Barros P P, da Silva FM, de Castilho Jacinto R, da Silveira Bueno C E. In vitro evaluation of the cleansing working time and analysis of the amount of gutta-percha or Resilon remnants in the root canal walls after instrumentation for endodontic retreatment. J Endod 2007; 33: 1426-1428

141. Hassanloo A, Watson P, Finer Y, Friedman S. Retreatment efficacy of the Epiphany soft resin obturation system. Int Endod J 2007; 40: 633-643.

142. Bodrumlu E, Uzun O, Topuz O, Semiz M. Efficacy of three techniques in removing root canal filling material. J Can Dent Assoc 2008; 74: 721.

143. Hammad M, Qualtrough A, Silikas N. Three-dimensional evaluation of effectiveness of hand and rotary instrumentation for retreatment of canals filled with different materials. J Endod 2008; 34: 1370-1373

144. lizuka N, Takenaka S, Shigetani Y Okiji T Removal of resin-based root canal filling materials with $\mathrm{K} 3$ rotary instruments: relative efficacy for different combinations of filling materials. Dent Mater $J$ 2008; 27: 75-80.

145. Somma F, Cammarota G, Plotino G, Grande N M, Pameijer $\mathrm{CH}$. The effectiveness of manual and mechanical instrumentation for the retreatment of three different root canal filling materials. J Endod 2008; 34: 466-469.

146. Taşdemir T, Yildirim T, Çelik D. Comparative study of removal of current endodontic fillings. Int Endod J 2008; 34: 326-329.

147. Ring J, Murray P E, Namerow K N, Moldauer B I, Garcia-Godoy F. Removing root canal obturation materials: a comparison of rotary file systems and re-treatment agents. J Am Dent Assoc 2009; 140: 680-688.

148. Zarei M, Shahrami F, Vatanpour M. Comparison between gutta-percha and Resilon retreatment. J Oral Sci 2009; 51: 181-185.

149. Fenoul G, Meless G D. Pérez F. The efficacy of R-Endo rotary NiTi and stainless steel hand instruments to remove gutta-percha and Resilon. Int Endod J 2010; 43: 135-141.

150. Marfisi K, Mercade M, Plotino G, Duran-Sindreu F Bueno R, Roig M. Efficacy of three different rotary files to remove gutta-percha and resilon from root canals. Int Endod J 2010; 43: 1022-1028.

151. Friedman S, Moshonov J, Trope M. Efficacy of removing glass ionomer cement, zinc oxide eugeno and epoxy resin sealers from retreated root canals. Oral Surg Oral Med Oral Pathol Oral Radiol Endod 1992; 73: 609-612.

152. Friedman S, Moshonov J, Trope M. Residue of gutta-percha and a glass ionomer cement sealer following root canal retreatment. Int Endod J 1993; 26: $169-172$

153. Moshonov J, Trope M, Friedman S. Retreatment efficacy 3 months after obturation using glass ionomer cement, zinc oxide-eugenol, and epoxy resin sealers. J Endod 1994; 20: 90-92.

154. Wiemann $\mathrm{A} H$, Wilcox L R. In vitro evaluation of four methods of sealer placement. J Endod 1991; 17: 444-447.

155. Verdelis K, Eliades G, Oviir T, Margelos J. Effect of chelating agents on the molecular composition and extent of decalcification at cervical, middle, and apical root dentin locations. Endod Dent Traumatol 1999: 15: 164-710.

156. Kosti E, Lambriandis T, Economides N, Neofitou C. Ex vivo study of the efficacy of H-Files and rotary $\mathrm{Ni}$-Ti instruments to remove gutta-percha and four types of sealer. Int Endod J 2006; 39: 48-54.

157. Vranas R N, Hartwell G R, Moon P C. The effect of endodontic solutions on Resorcinol-formalin paste. J Endod 2003; 29: 69-72.

158. Shokouhinejad N, Sabeti M A, Hasheminasab M, Shafiei F, Shasmshiri A R. Push-out bond strength of Resilon/Epiphany self-etch to intraradicular dentin after retreatment: a preliminary study. J Endod 2010; 36: 493-496.

159. Torabinejad M, Kutsenko D K, Machnick T K, Ismail A, Newton C W. Levels of evidence for the outcome of nonsurgical endodontic treatment. J Endod 2005; 31: 637-646.

160. Cotton T P, Schindler W G, Schwartz S A, Watson W R, Hargreaves $K$ M. A retrospective study comparing clinical outcomes after obturation with Resilon/Epiphany or gutta-percha/Kerr sealer. J Endod 2008; 34: 789-797.

161. Conner D A, Caplan D J, Teixeira F B, Trope M. Clinical outcome of teeth treated endodontically with a nonstandardized protocol and root filled with Resilon. J Endod 2007: 33: 1290-1292. 